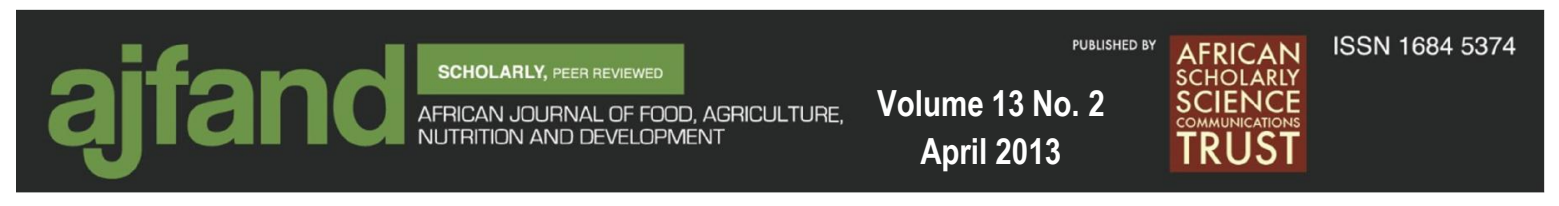

\title{
POTENTIALS OF HYBRID MAIZE VARIETIES FOR SMALL-HOLDER FARMERS IN KENYA: A REVIEW BASED ON SWOT ANALYSIS
}

\author{
Schroeder $C^{1}$, Onyango K'Oloo $\mathbf{T}^{\mathbf{1}}$, Ranabhat NB $^{1}$, Jick NA ${ }^{\mathbf{1}}$, \\ Parzies HK $^{1^{*}}$ and DC Gemenet ${ }^{1,2}$
}

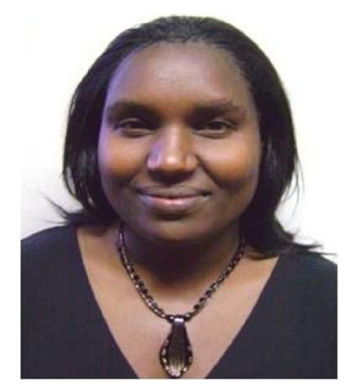

Dorcus Chepkesis

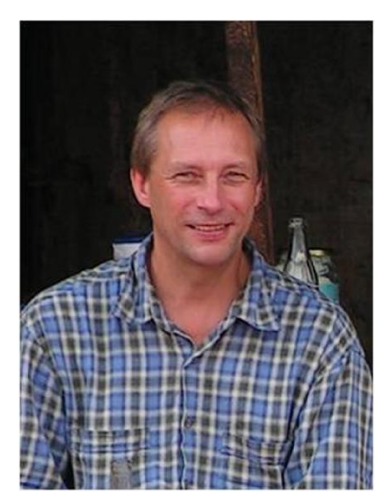

Heiko Parzies (Late)

*Corresponding author email: chepkesis@yahoo.com

${ }^{1}$ University of Hohenheim, Institute of Plant Breeding, Seed Science and Population Genetics, Fruwirthstr. 21, D-70599, Stuttgart, Germany;

${ }^{2}$ Kenya Agricultural Research Institute, Kakamega, P.O Box 162 50100, Kakamega 


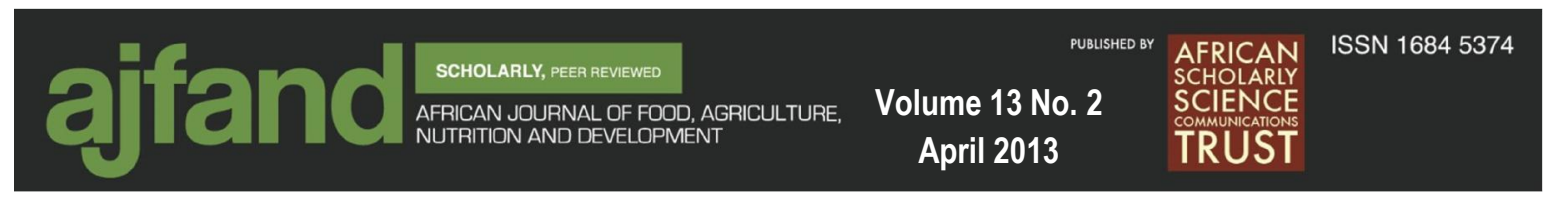

\begin{abstract}
Maize is the primary staple crop in Kenya and plays an important role in the livelihood of the people of Kenya. Its availability and abundance determines the level of welfare and food security in the country. In Kenya, future increases in maize production to meet domestic demand will have to rely on improvements in yield per hectare rather than on the expansion of maize production area. Enhanced maize productivity can be achieved by increased use of modern production techniques such as the adoption of hybrid maize varieties, the use of chemicals and fertilizer application. Small-scale maize prodcution plays a major role in Kenya's maize economy and adoption of hybrid technology by small-scale farmers would have the potential to address sustainability and supply issues. However, such modern technologies are still rarely used by Kenya's small-scale farmers, particularly by those in marginal areas. This study, therefore, tries to review the reasons for the low rate of adoption of hybrid maize varieties among small-scale farmers with focus on those smallholders in Kenya's marginal areas. Lack of awareness of existing or newly released hybrid varieties, lack of hybrid varieties adapted to marginal areas, lack of confidence in the quality of some hybrid maize seeds, poor access to stockists, low profitability due to high seed cost, inadequate access to credit, the need for fertilizer application and low literacy level have been found to be important factors explaining the low adoption rates by smallholder maize producers in marginal areas. In addition, these constraints might also explain the widespread practice of recycling hybrid grain among small-scale farmers once they have adopted hybrid maize varieties. Therefore, it is hoped that by overcoming these constraints, the adoption of hybrid maize varieties among smallholder farmers could be greatly enhanced, which in turn could lead to a significant positive impact on the country's food security situation.
\end{abstract}

Key words: Adoption, maize hybrids, small-scale farmers 


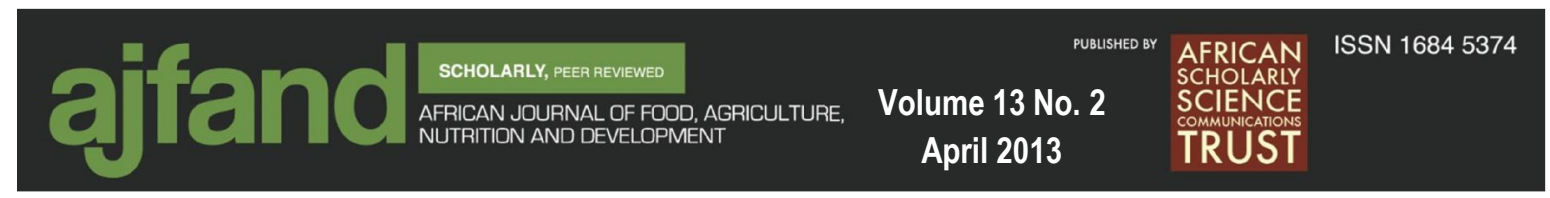

\section{INTRODUCTION}

Maize is the main staple food in Kenya [1]. It is estimated to account for more than $20 \%$ of total agricultural production, and $25 \%$ of agricultural employment [2]. According to FAO statistics (2005-2007), maize contributes about $68 \%$ of daily per capita cereal consumption, $35 \%$ of total dietary energy consumption and $32 \%$ of total protein consumption [3]. Thus, Kenya's national food security is strongly linked to production of adequate quantities of maize to meet an increasing domestic demand [4]. Kenya has 1.6 million hectares of maize area and there is limited scope for further expansion since most of the arable land in Kenya is already under cultivation [5-6]. Therefore, future increase in maize production will rather be achieved by improving yield per hectare than by expanding production area. The average maize yield is about $1.8 \mathrm{t} / \mathrm{ha}$ but a yield potential of over $6 \mathrm{t} / \mathrm{ha}$ is possible $[5,7]$. This yield potential could be exploited by focusing on improving maize yields particularly in marginal areas. This could be achieved through the adoption of productivity improving technologies such as increased use of hybrid maize and application of fertilizer by small-scale maize producers who make up $70 \%$ of the country's maize production $[2,8-10]$.

Since the initiation of a comprehensive maize program in Kenya in the 1960s and 1970s, improved maize hybrids have diffused only slowly and gradually in the low potential areas as opposed to the high potential areas (highland tropics and moist transitional zone) where hybrids are adopted by over $90 \%$ of the farmers and account for a large proportion of the maize area planted (Table 1) [9, 11-12]. A large proportion of small- holder farmers in marginal areas still use local varieties and prefer improved open-pollinated varieties (OPVs) over hybrids (Table 1). It has, however, been shown that well-adapted maize hybrids could perform profitably in terms of yield and yield stability even in marginal production environments under low input conditions [13-15]. This, therefore implies that well adapted maize hybrids would offer a significant potential to increase yields even under marginal agroclimatic conditions. This study sought to explore why maize hybrids are not widely adopted by small-scale farmers in Kenya, especially in the low-potential areas. This was achieved through literature review, administration of a simple questionnaire to document first hand information related to the study and a subsequent SWOT analysis based on the two sets of data.

\section{Background information and study findings}

Development of maize hybrid breeding and maize hybrid seed industry in Kenya Maize improvement efforts by various researchers and farmers date back to as early as $1920 \mathrm{~s}$. The government of Kenya responded to the demands by large-scale maize farmers by initiating a systematic germplasm improvement program in 1955 [16]. This led to the development of late maturing varieties. Later, early maturing varieties were developed for marginal areas. In Table 1, a summary overview of the recommended varieties for selected sites in each agro-ecological zone is represented. 


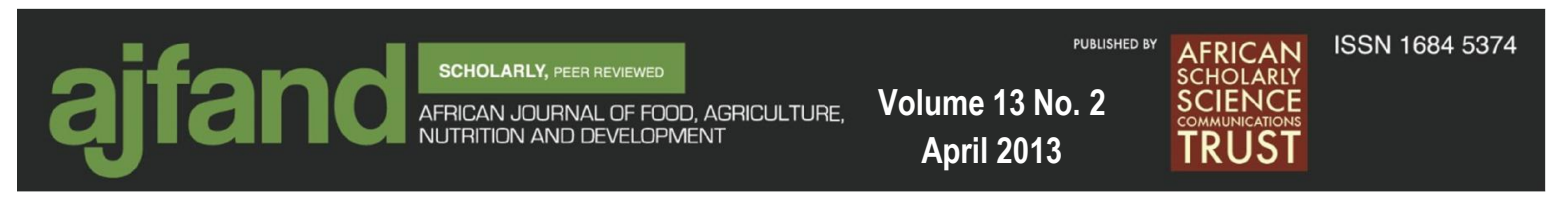

The first maize hybrid released in Kenya was H611, in 1964 [16-17]. It was a cross between Kitale Synthetic II, an open-pollinated variety (OPV) and an improved Equadorian landrace (Equador 573). H611 had a 40\% yield advantage over Kitale Synthetic II, had lower seed costs than conventional hybrids and had lesser loss of yield when recycled [17]. This formed the basis of maize hybrid development in Kenya. It diffused among the large-scale and small-scale farmers in the high potential areas of Western Kenya at a high rate. Currently, there are many maize hybrid varieties being relaesed every year for the different agro-climatic zones (Box 1; Figure 1), though the adoption rate has not kept up with the pace of release.

The first mark of formal seed trade was made by the establishment of the Kenya Seed Company (KSC) in 1956. The main business of KSC is maize and it covers up to $90 \%$ of the formal marketed maize hybrids in Kenya. Until 1985, KSC relied on the varieties developed by the National Agricultural Research Program of the Kenyan Agricultural Research Institute (KARI). However since liberalization, many actors have come into play in the formal seed sector and KSC has also increased its scope and has intensified breeding programs for many other crops such as, wheat and sorghum. Today, the formal seed sector has attracted a number of specialized players, both public and private ones who are involved either directly or indirectly in areas such as breeding, seed multiplication, quality control, processing storage, marketing and seed distribution [18].

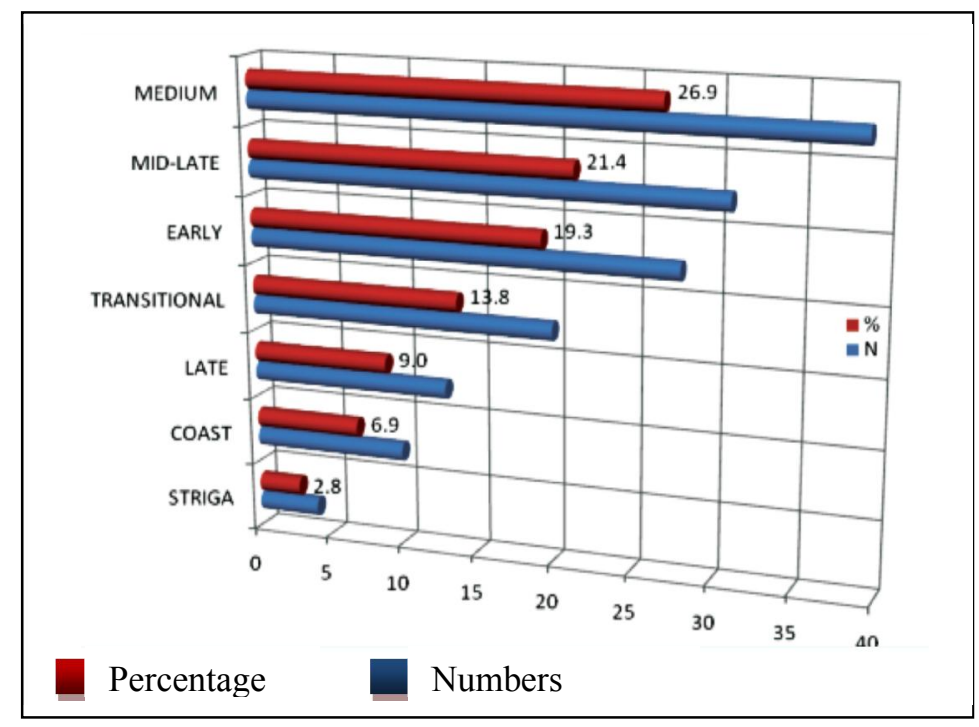

Figure 1: The proportion of maize varieties submitted for NPT 2008 - 2009 [19]

The formal seed sector in Kenya is among the strongest and one of the best functioning seed sectors in sub-Saharan Africa. This is evidenced by the volume and level of diversity of the seed produced and availed in the market, the existing legislative and regulatory frameworks and the availability of a functioning certification system and procedures for testing and approval of new varieties [18]. 


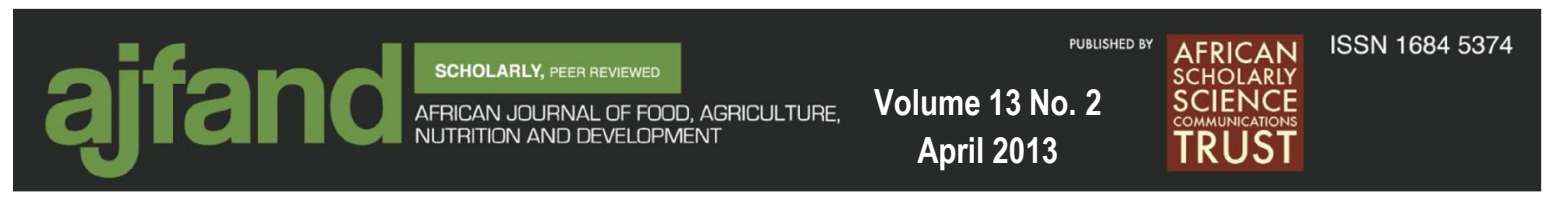

According to Kenya Plant Health Inspectorate Services (KEPHIS) Annual report (2010), there were a total of 111 maize varieties submitted for National Performance Testing (NPT) during the $2008-2009$ period [19-20]. The proportion of maize varieties submitted for NPT $2008-2009$ is shown in Figure 1.

\section{Agroecological zones and varieties released}

Maize crop is grown in all agroecological zones in Kenya by both large-scale and small-scale farmers. Hybrid varieties are released with respect to different agroecological zones. The white semi-dent grains have been bred and selected for suitable climatic conditions and altitudes above sea level [20].

\section{a) Highland maize varieties}

These are varieties suitable for medium to high altitude areas (1500-2100 m) with day temperatures of up to $28^{\circ} \mathrm{C}$ during the growing season and with night temperatures dropping to as low as $8^{\circ} \mathrm{C}$. H627, H626, H625 are some of the varieties released for the highlands. Precipitation requirements range from 800 to $1500 \mathrm{~mm}$. Similar conditions also prevail in the highlands of Tanzania, Uganda, and Ethopia so that these varieties are recommended there too [20].

\section{b) Medium altitude agro-ecozone}

The zone of medium altitude falls between 1000 to $1700 \mathrm{~m}$ of altitude. H513, H515, $\mathrm{H} 516$ are some of the varieties recommended for this agro-ecozone. These varieties are commonly planted in coffee growing belts maturing in four to five months. Rainfall is favourable when it measures between 750 and 1000mm [20].

\section{c) Transitional zone}

The transitional zone can be found at altitudes of 1000 to $1700 \mathrm{~m}$ with temperatures of $12^{\circ} \mathrm{C}$ to $30^{\circ} \mathrm{C}$ and with rainfall patterns similar to those of high altitudes (1000$1800 \mathrm{~mm})$. For this zone, H624, H623 are typical examples. Their characteristics: highly prolific, short, green-stemmed, 150 days from planting to maturity. These varieties produce huge thick cobs and large dent kernels. In Kenya they perform better in wet, humid, medium to high elevations [20].

\section{d) Lowland agro-ecozone}

Pwani Hybrids (PH1 and PH4) were released in 1987. They are fairly short and resistant to lodging and more tolerant to moisture stress (altitude 0-1250 masl) and require minimum rainfall of $400 \mathrm{~mm}$. They have a good husk cover which reduces crop loss due to attacks, for example, by birds, weevil. They are suitable for intercropping, highly productive and capable of producing 16 bags of grain per hectare under good agronomic practices. They are uniform, short and tolerant to most leaf and ear diseases and mature within three to four months [20].

\section{e) Dryland transitional agro-ecozone}

The Katumani Composite (KCB) is a short and fast growing open-pollinated variety and produces short cobs. This variety is drought escaping and matures within 90-120 days. It performs well in altitudes of $500-1000 \mathrm{~m}$ above sea level and is especially 


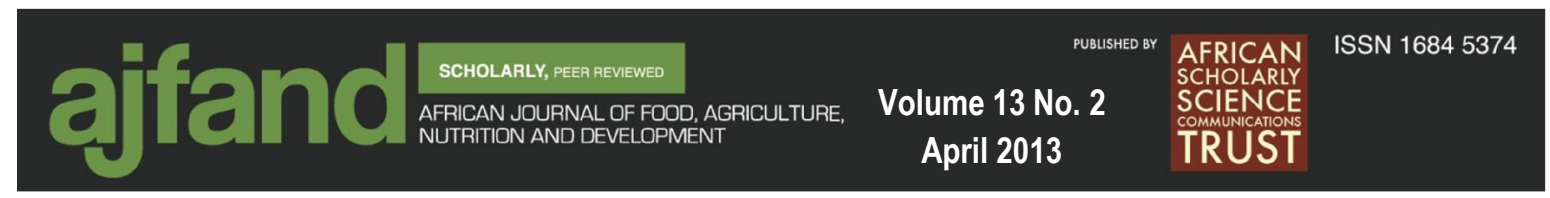

suitable for areas with marginal rainfall. The variety's rainfall requirements are 250$500 \mathrm{~mm}$ and it has performed excellently well in arid zones of Ethopia, Sudan, Tanzania and Namibia [20].

\section{f) Dryland mid- altitude agro-ecozone}

For this zone, recommended varieties are Dryland Compite 1 (DLC1) and Dryland Hybrid 1 (DH01). These are open-pollinated varieties, good for semi-arid regions (altitude 1000-1900m). They are best suited to areas with short rainy seasons (minimum $350 \mathrm{~mm}$ ) and are good substitutes for Katumani Composite where rainfall is erratic. The varieties are commonly grown in the Eastern and Coastal regions of Kenya. They mature within three to four months and can produce 14 bags per acre. They are short, uniform and tolerant to most ear diseases [20].

\section{Characteristics of smallholder maize farming in Kenya}

Smallholder farmers grow maize either as a sole crop or as an intercrop, but intercropping is more prevalent for the vast majority of small farms in all agroecological zones $[8,13,21]$. So, in Kenya's smallholder sector, maize is commonly intercropped with a number of short-term crops such as sunflower, groundnut, millet, potatoes and above all beans or cowpeas $[13,21]$. Intercropping maize with beans is particularly practiced in Striga endemic areas [22]. Besides being a practical means for pest management, intercropping is also practiced by Kenya's smallholders due to other reasons such as high population density and increasing pressure on land, riskspreading through crop diversification, improvement of soil fertility and erosion protection, and higher yields per unit area compared to pure stands [21, 23]. Major stress factors and productivity constraints maize farmers in Kenya have to face are, for example, rainfall variability and drought, low soil fertility and erosion, diseases and pests [13]. The most common pests, according to farmers, are Striga, stem borer and weevils $[4,14]$. Further constraints to maize production are, inter alia, poor cash flows and lack of technical know-how [4, 14]. Consequently, it is important to consider these factors more closely to estimate if and how the adoption rate of maize hybrids could be improved among small-scale farmers, particularly in low-potential areas.

\section{The adoption process}

Adoption is one important component within the innovation-decision process, according to Rogers [24]. The innovation-decision process is "the process through which an individual passes from first knowledge of an innovation to forming an attitude toward the innovation, to a decision to adopt or reject, to implementation and use of the new idea, and to confirmation of this decision" [24]. Consequently, the innovation-decision process is composed of five main steps (Figure 2):

(1) Knowledge is being aware of the existence of an innovation [24].

(2) Persuasion is the process of forming a favorable or unfavourable attitude towards the innovation [24]. 


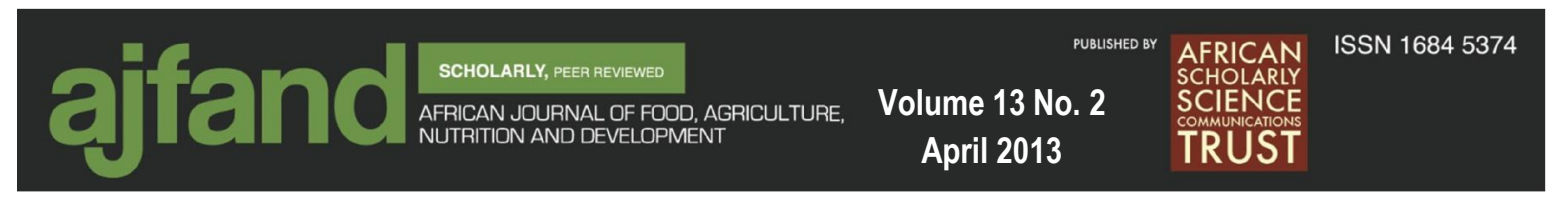

(3) Decision means making a choice whether to adopt or reject the innovation [24].

(4) Implementation is the logic consequence of the adoption and means putting an innovation into use [24].

(5) Confirmation involves the re-enforcement or the reversing of a previous innovation-decision [24].

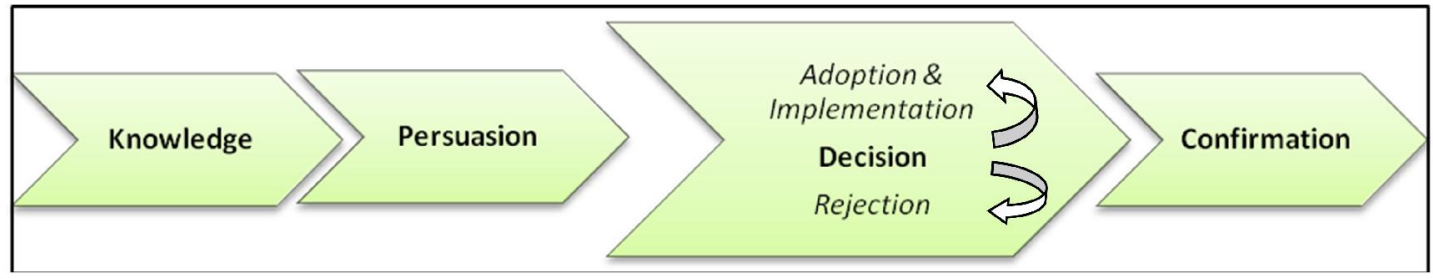

Figure 2: Innovation-decision process [Own depiction]

To sum up, the decision stage in the innovation-decision process leads to adoption. Adoption is thus "a decision to make full use of an innovation at the best course of action available" [24]. When it comes to the use of modern varieties (MVs) of maize, one speaks of adoption when a farmer is changing from planting traditional varieties to planting modern varieties [25]. The term "modern varieties" includes both improved-open pollinated varieties (OPVs) and hybrids [25]. The term traditional varieties refers to local varieties (also known as landraces), which have never been subject to a formal plant breeding program [25]. Instead of using the term adoption, the term replacement is often used. Replacement refers to the activity when a farmer "who is already growing MVs stops planting one and starts planting another" that means, for example, the shift from improved OPVs to hybrids[25].

Finally, the adoption process of maize hybrids by smallholders to adopt hybrid maize is influenced by various factors. Those factors which have been frequently identified as being influential will be discussed in the following section.

Possible factors affecting adoption of maize hybrids among smallholder farmers In a number of studies, possible causes of low adoption rate of improved maize varieties such as hybrids among small-holder farmers have been analyzed. The most cited constraints to adoption are:

\section{(1) Lack of information and awareness}

Farmers' awareness of existing or newly released hybrid varieties strongly depends on their access to agricultural information. An important source of information is extension. Adequate access of farmers to extension providers increases the likelihood of adopting new technologies like hybrid maize (Table 1). Hassan et al. [26] showed that there might be a possible correlation between access to extension services and farmers' awareness of the new technology / farmers' adoption. The percentage of farmers indicating lack of awareness about improved seeds was higher in zones with a 


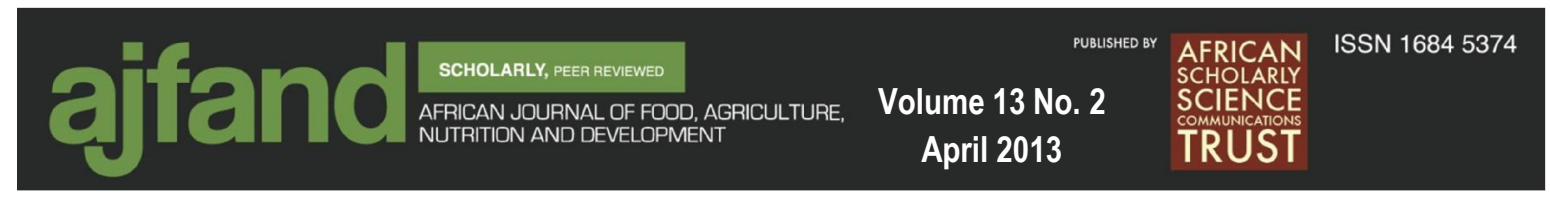

poorer coverage by extension agents than in zones with better supply of extension services [26]. Also when referring to Tegemeo Institute/MSU TAMPA household survey data, it is noticeable that proximity to extension services appears to be correlated with the farmers' adoption of productivity enhancing technologies such as hybrid maize seeds [27]. The correlation between the use of maize hybrid seed, inorganic fertilizer, and distance to nearest extension service as well as yields showed that farm households which are located closer to an extension service provider, also use the new technologies [27]. Hassan et al. [26] further showed that access to extension services might be correlated with the infrastructure of the country, for example, the availability of paved roads. Besides access to extension, also the quality of the extension service provided must be adequate which means adjusted to the needs and circumstances of the target group. In addition to 'professional' extension providers, seed retailers also play an important role in the context of farmer education and awareness creation because they should inform the farmer sufficiently about the characteristics of the seeds they sell. However, some of the seed retailers lack sufficient knowledge to fulfill this necessary task [28].

\section{(2) Supply constraints}

\section{a) Lack of adapted maize hybrids}

In the past, maize research mainly concentrated on high-potential areas. For these areas, well-adapted maize hybrids were developed and released. Low-potential areas, however, received little attention, so that the farmers in these areas were lacking hybrid varieties that were adapted to their distinct agro-ecological conditions. Therefore, farmers opt for landraces or improved OPVs because theses varieties are, due to their wider genetic base, more adapted to prevailing production constraints such as low soil fertility, weeds such as Striga, drought and diseases [4]. According to a KARI breeder, the International Maize and Wheat Improvement Centre (CIMMYT) and Kenya Agricultural Research Institute (KARI) are currently shifting their research efforts more and more on marginal areas and are focusing on the development of hybrid cultivars that are better adapted to stress environments [29]. In doing so, it is important that the interaction and communication between breeders and farmers be improved and that breeding does not take place only from the perspective of the breeder but rather allows for participation of farmers [30]. Only then can hybrid varieties be developed which will carry those attributes and characteristics that farmers are generally interested in [29-30].

\section{b) Availability of good quality seed}

Often it is not the lack of information about existing hybrid varieties, but rather the lack of confidence in hybrid seed quality that negatively affects adoption. This lack of confidence originated in the 1990s when farmers in Kenya experienced reduced quality of maize seed despite the liberalization of the seed industry and the establishment of the independent seed inspection authority, KEPHIS [31]. The poor quality of certified maize seeds resulted in poor germination and low yields [31]. Farmers who were willing to adopt these certified seeds were then disappointed and thus opted again for local varieties or retained seeds [31]. So, good quality seed is important to win back farmers' confidence in certified hybrid seeds. 


\section{c) Access to stockists}

The existence of efficient input markets is essential for farmers in deciding whether to adopt agricultural technologies or not. In Kenya, market liberalization facilitated the emergence of so-called 'stockists' [32]. These stockists, also known as "agrodealers" or "small farm retailers" are an important distribution channel for smallholder farmers in rural areas because they sell agricultural inputs such as fertilizer, pesticides and improved seeds ("certified seeds of commercially released varieties") and can provide knowledge about safe and efficient input use [32-35]. Access to these agro-dealers is therefore an important determinant of the adoption of hybrid maize varieties [26]. In Kenya, there is an uneven geographical coverage of such "traders in agricultural inputs" [35]. In marginal, low-potential areas which are often characterized by a lower density of stockists, smallholder farmers need to travel longer distances, often on poorly maintained roads or by foot, to purchase inputs such as improved seeds [33, 35]. This leads to higher transaction cost which in turn increases the costs of improved maize seeds [26]. Higher seed costs on the other hand reduce the profitability of new varieties and thus the incentive for farmers to use them. Consequently, among other factors influencing the adoption of improved maize seeds, one can observe a negative correlation between the distance (farm household stockist) and the adoption rate [26]. In addition, it is important that the hybrid variety the farmer prefers is actually continuously available in stockists' stock [36]. As yields of hybrid varieties are much higher when fertilizer is applied, it is highly recommended that stockists also offer fertilizer so that the farmer can purchase both seeds and fertilizer from one single source. Easy access to both fertilizer and improved seeds increases the likelihood that farmers are willing to adopt hybrid maize.

\section{(3) Low profitability}

Farmers often cite the high cost of hybrid seed as a constraint to adoption [29]. The high seed price results both from high cost of developing and producing hybrid seeds and from high transportation costs [26, 37]. In particular, maize hybrid seed is not economically profitable for resource-poor farmers when the seed-to-grain price ratio is unfavorable [26].

\section{(4) Lack of access to credit}

Access to credit plays an important role in farmers' decision to adopt new maize technologies. Credit has the potential to relax farm-level liquidity constraints which are the reason for smallholders not being able to purchase productivity enhancing technologies such as improved maize varieties and fertilizer [31, 38]. Furthermore, the ability to borrow money increases a farm household's ability to bear risk [39]. So, with the option to access credit smallholder farmers are more willing to shift from traditional low-risk, low-return farming practices such as the use of local maize varieties to riskier and more profitable agricultural technologies such as planting hybrid maize. Smallholders' access to financial services from the formal banking sector such as commercial banks is, however, often limited by the lending policies of those institutions [40]. These lending policies constrain the supply of credit to 


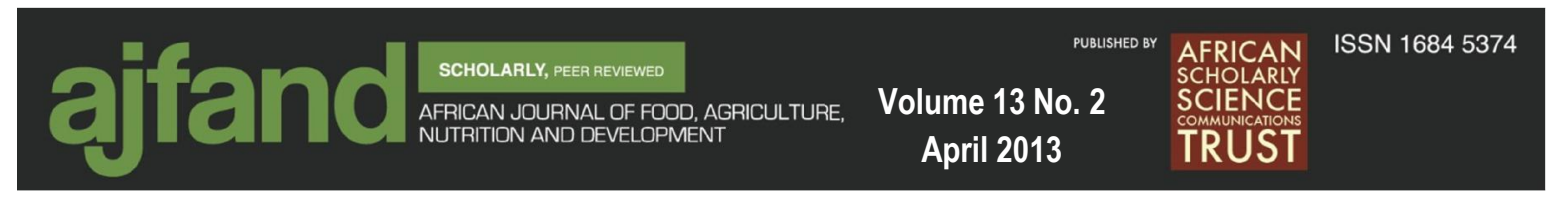

smallholders by, for example, requiring collateral or setting a minimum credit amount [40]. Moreover, high risks involved in agricultural activities are frequently a decisive argument for creditors not lending to this sector [41-42]. In Kenya, the situation is similar. For Kenyan smallholder farmers, credit from the formal sector, that is commercial banks, and the government's Agricultural Finance Cooperation (AFC) has been a critical issue [43]. So, for example, in 1998, only one percent of AFC credit was made to medium and small-scale farmers [43]. However, the government of Kenya has recognized the existing credit problem and is attempting to improve access to credit for smallholder farmers. Within the current Agricultural Sector Development Strategy 2010-2030, the government of Kenya plans to promote the following measure: "appropriate credit packages suitable for small-scale producers will be made available to enable producers to access key inputs such as fertilizer, agrochemicals and seed" [42]. The Alliance for a Green Revolution in Africa (AGRA) is also active with a program in Kenya. Within the Innovative Financing Initiative to improve smallholders' access to affordable finance, AGRA in cooperation with the International Fund for Agricultural Development and the Kenya's Equity Bank provide funds for issuing loans to small-scale farmers [44]. In 2009, the program loaned more than 679 million Kenyan shillings (about US\$9.8 million) to 20,408 beneficiaries of which 19,931 were small-scale farmers [44].

\section{(5) Need for fertilizer}

To exploit the full yield potential of maize hybrids, it is necessary to apply an optimal level of fertilizer [31]. So, for example, most commercial maize hybrids are performing poorly on soils with low nitrogen levels because they have been developed in research stations with soils of optimum nitrogen conditions [45]. Consequently, for achieving optimal grain yields, smallholders should apply fertilizer and use it efficiently, which means in recommended amounts. However, although fertilizer has become more available in Kenya in the course of the liberalization of the agricultural sector, the high cost of these chemicals often resulting from high transportation costs still constrains the adoption and the use of reasonable quantities of fertilizer in resource-poor farm households [46-47]. As already mentioned, these households often lack cash and credit to purchase hybrid seeds and fertilizer. As productivity gains from hybrid seeds can only be fully realized if fertilizer is applied and used efficiently, it is assumed that constraints to fertilizer use hamper the demand for hybrid seeds [47]. Indeed, the adoption study of Ouma et al. [48] shows that farmers who are using more fertilizer are more likely to adopt improved maize varieties than those using less fertilizer. Furthermore, the study indicates that the amount of fertilizer used positively correlates with the intensity of use of improved maize varieties [48].

\section{(6) Low level of education}

The level of education plays an important role in farmers' decision making and thus in the adoption of improved maize production technologies. Educated farmers usually have a better opportunity to access information on new technologies and are generally better able to assimilate, to process and to use this information. Several adoption studies demonstrated that education increases the probability of adoption of improved 


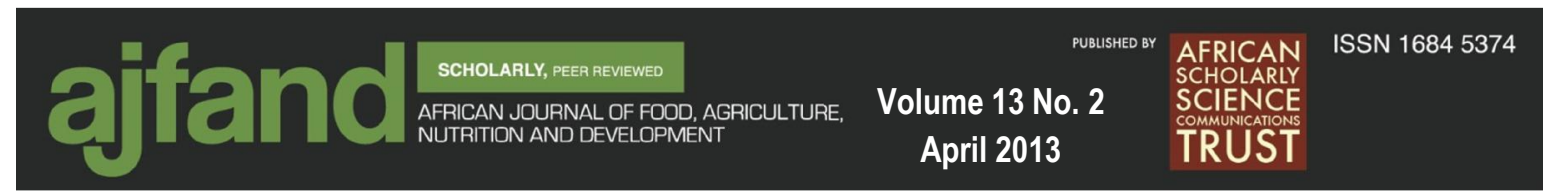

maize technology, indicating that better-educated farmers are more likely to grow improved maize varieties such as hybrid maize [39, 49-50]. The importance of education on adoption thus emphasizes the relevance of extension and training for smallholder farmers in the adoption process.

In summary, the constraints discussed under (1) to (6) explain why smallholder farmers in marginal areas (for example the dry transitional, dry mid-altitude, moist mid-altitude zones) still plant a high share of maize area using local varieties ('unimproved' OPVs) and improved OPVs. In addition, these constraints are the reason that even if hybrids have been adopted, farmers use recycled hybrid grain.

\section{Hybrids, OPVs and the practice of recycling}

One important question needs further analysis and reflection: Instead of purchasing new hybrid seeds every year, is recycling of hybrid maize and/or the use of OPVs a profitable economic option for resource-poor farmers [51]?

A study conducted by Pixley and Bänzinger [51] in Zimbabwe can shed light on this issue. They reported that the yield potential of good maize hybrids from first generation (F1) seed is around 18\% higher than that of good OPVs. Also, Chiduza et al. [52] compared at eight different farmers' fields in Zimbabwe the grain yield of ten experimental open-pollinated varieties and five released maize hybrids, grown with and without fertilizer application. They also reported that at all eight environments, grain yields for the hybrids were consistently higher when compared to those of the five highest yielding OPVs - by an average of $16 \%$ without fertilizer and of $19 \%$ with fertilizer [52]. In addition, Chiduza et al. [52] found out that without fertilizer the yield difference between OPVs and hybrids was smaller at sites where yield levels were low (which means mean grain yield below 1.3t/ha). Then, the seed-to-grain price ratio decides whether hybrids or OPVs are more economically profitable for the farmer. So, when the price of hybrid seed is high compared to the grain price, resource-poor farmers should plant OPVs for which costs of seed are lower [51].

When it comes to recycling of seeds, Pixley and Bänzinger [51] reported the following results: if second-generation ('recycled') seed of both OPVs and hybrids is used, then OPVs are higher yielding than hybrids. So, regarding grain yield the following formula applies: hybrid $>$ OPV $>$ recycled $\mathrm{OPV}>$ recycled hybrid [51]. Consequently, in marginal areas where yield levels are low, then, if the price of hybrid seed is high compared to the grain price and if fertilizer application is constrained, it is more profitable for resource-poor farmers to use OPVs or recycled OPVs than to purchase new hybrid seeds annually [51]. Recycling of hybrid seed is a non-recommendable economic alternative [51]. This, therefore, highlights the importance of conserving the local varieties either in-situ or ex-situ despite maize hybrid production and promotion efforts. This will offer the farmers a safety net in terms of stability where necessary, and will also serve as a genetic reservoir in breeding programs for those traits that interest the farmers. 


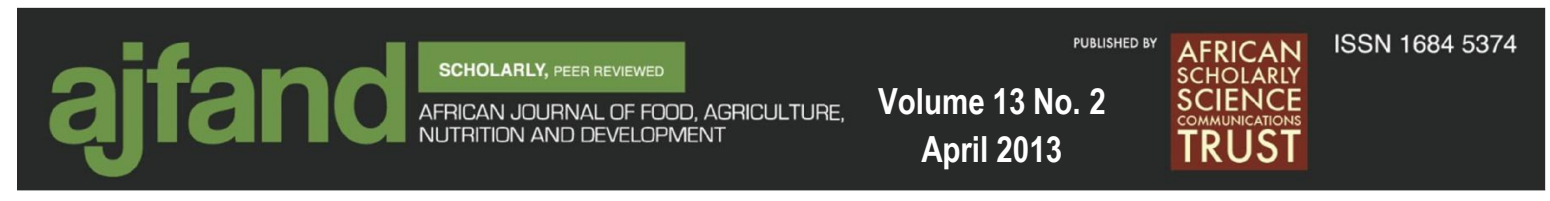

From Theory to Practice: Adoption of maize production technologies in the Coastal Lowlands of Kenya

In order to illustrate practical adoption experiences with improved maize varieties in Kenya, a study conducted by Wekesa et al. [1] in two districts of the Coast Province provides a useful insight. The following statements and figures are cited from this study [1]. This adoption study surveyed 200 households in the Kilifi and Kwale District of the Coast Province, Kenya. In the Coast Province, maize is an important food crop and mostly grown for subsistence [1]. However, average yields are low resulting in food deficits [1]. For the coastal lowlands, in which the Coast Province is situated, three improved maize varieties were developed and released: the openpollinated Coast Composite, the hybrids Pwani 1 (PH1) and Pwani 4 (PH4) [1]. Despite the potential of these improved varieties to increase yields however, adoption has remained low (only 21\% of farmers grew Pwani Hybrid 1) and local varieties continued to be used by $70 \%$ of the farmers [1]. The objective of the study conducted by Wekesa et al. [1] was to analyze factors affecting the adoption of modern varieties by focusing on the two districts Kilifi and Kwale. An adopter of improved maize varieties was considered a farm household that used certified seed on at least one acre of land [1]. Fourty percent of the sample households included improved maize seed in their variety portfolio [1]. However, the three released and recommended improved maize varieties for the region were not as popular as the local varieties. So, local varieties were still grown by $70 \%$ of the survey households [1]. Among the improved varieties, the open-pollinated Coast Composite was the most used, followed by Pwani Hybrid 1, whereas Pwani Hybrid 4 was only grown by five percent of the sample farmers [1]. One possible explanation that Pwani Hybrid 1 was preferred over Pwani Hybrid 4 is that farmers like the attribute of 'early maturity'. Pwani Hybrid 4 needs 120 days to maturity whereas Pwani Hybrid 1 only requires 105 days to maturity [50]. The factors farmers mostly mentioned as reasons for not adopting improved maize varieties were the following [1]:

$>$ Non-availability of improved maize seed (29\% of farmers)

$>$ High cost of seed (22.5\%)

$>$ Lack of awareness and information (13\%)

$>$ Inappropriate attributes of the varieties, for instance, pest vulnerability (10.5\%)

In a logit regression model, the study further analyzed explanatory variables of adoption and their significance. The output of this regression shows the following factors which had a significant impact on adoption: Extension contact and listening to agricultural radio programs, availability of credit, availability of cash - off-farm income and hiring labor were used as a proxy - and farmers' participation in training courses [1].

Furthermore, when the adopters of improved maize are compared to the non-adopters, further factors can be identified that might positively influence the farmers' decision to adopt new maize varieties. However, these factors are not significant in the regression model but might be decisive: the literacy rate was higher for adopters (75\%) than for non-adopters (61\%); the household size among adopters (11 members) 


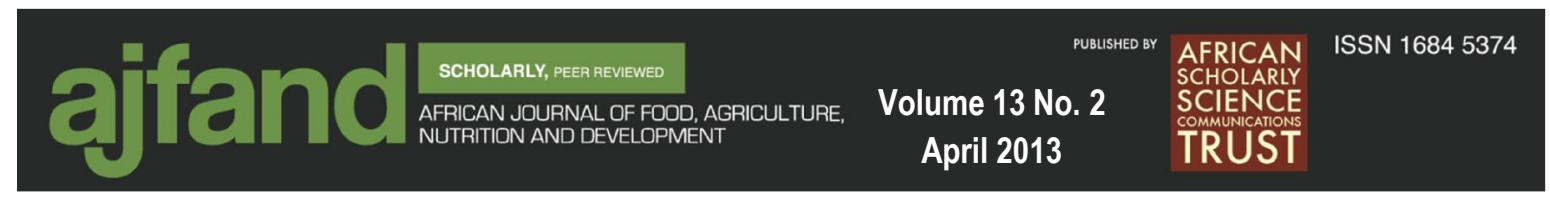

was larger than among non-adopters (eight members); adopters planted more acres to maize than non-adopters (3.7 acres for adopters and 2.6 acres for non-adopters); the total income of adopters was higher than that of non-adopters $(43,000 \mathrm{Ksh} / \mathrm{yr}$ vs. $30,000 \mathrm{Ksh} / \mathrm{yr}$; Ksh = Kenya shilling) [1].

In summary, there are a lot of factors which need to be considered if a new improved maize variety shall find acceptance among farmers. Thereby, a close cooperation and interaction between farmers, researchers, extension agents and policymakers might be necessary to meet the challenges in the field of adoption.

\section{First hand information from actors in the maize industry}

As an additional step to bridge the gap between literature review and the current situation on the ground, a questionnaire in line with the topic of the study was designed and sent out to various actors in the maize seed industry in Kenya. These included breeders from both public and private institutions as well as key experts from universities, seed companies and certification bodies involved in the research, production, marketing and production of maize hybrid seeds. The questionnaire contained 15 questions covering the following topics: physiology of maize hybrids, practices and production constraints of maize hybrid farming, performance of the certification process as well as market and adoption related issues. A copy of the questionnaire is included as supplementary material. Although it was sent out to a target of 43 people, only five responses were received. The feedback received unanimously supported the following important arguments which have already been raised and elaborated in the previous section:

Smallholders in low potential areas prefer improved OPVs and landraces over maize hybrid varieties due to their wider genetic base and the possibility to recycle these seeds. However, recycling of hybrid seeds leads to reduction in yield;

$>$ The seed certification process is believed to be well functioning;

$>$ The price instability of maize combined with the high cost of hybrid seeds reduces the attractiveness of maize hybrids varieties to farmers;

$>$ High nutrient requirement of maize hybrids combined high cost of inorganic fertilizer is a constraint to adoption by resource poor farmers;

$>$ To increase the acceptance of maize hybrids among smallholder farmers in marginal areas, there is need to develop hybrid varieties that are adapted to these environmental conditions. Some level of heterogeneity would be necessary to cope with the environmental shocks;

Some other factors that might influence adoption as had mentioned include, inter alia: Seed supply constraints and lack of access to credit and markets. 


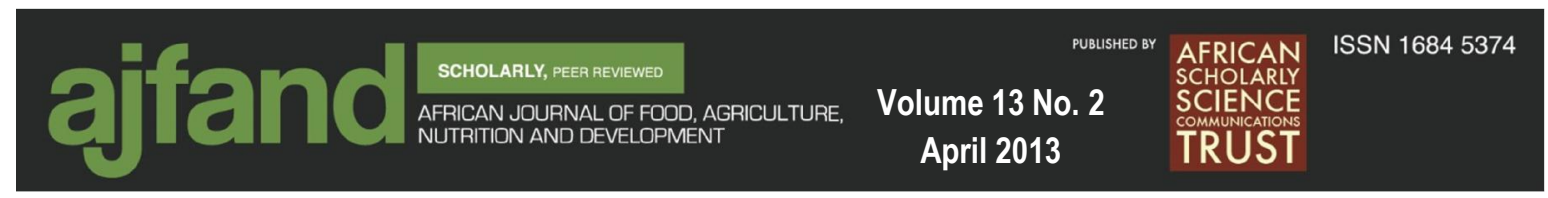

\section{SWOT analysis}

The SWOT analysis is an analytical tool which is commonly used to identify and assess the (internal) Strengths and Weaknesses, as well as the (external) Opportunities and Threats of, for example, projects, institutions, organizations or businesses [53]. This simple tool creates a picture of the current 'reality' and thus serves as an instrument for situation analysis and diagnosis [53]. The process of developing a SWOT analysis helps identifying problems, constraints and needs as well as determining strategies and actions for achieving goals and objectives [53].

The SWOT analysis approach in this paper is applied to examine the merits, benefits, potentials, risks and impacts of the improved hybrid maize technology for smallholder farmers in Kenya. The SWOT analysis is done based on existing data as well as information from questionnaire responses received in this study. In detail, the SWOT analysis consists of analysis of internal and external factors:

1. An analysis of the internal (inherent) factors of the technology in terms of its strengths and weaknesses. This should take into account both the main 'assets' of the technology that favor its adoption and application as well as the major deficits that prevent satisfying the needs and demands of potential users;

2. An analysis of the external environment within which the technology used is embedded. Opportunities are any factors that positively affect the adoption of hybrid maize in marginal areas whereas threats are any constraints that influence the use of the technology and that limit the full exploitation of its potentials.

Figure 3 shows the application of a SWOT analysis on the topic of this article. 


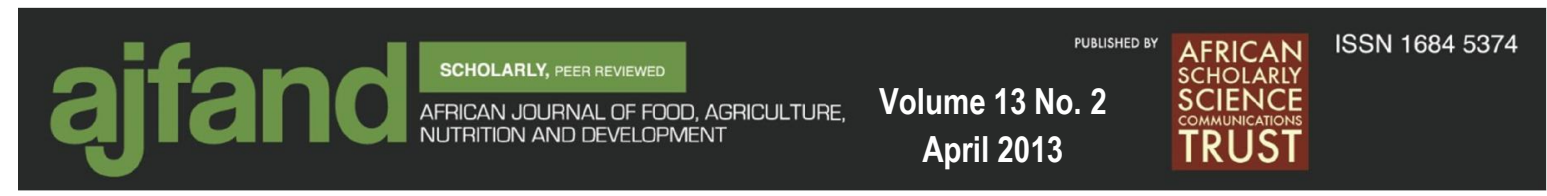

\begin{tabular}{|c|c|c|}
\hline $\begin{array}{l}\text { Environmental } \\
\text { factors }\end{array}$ & $\begin{array}{l}\text { External Opportunities } \\
\text { - High demand for maize } \\
\text { - Unexploited market for } \\
\text { hybrid maize } \\
\text { - Effective certification } \\
\text { body } \\
\text { - Available legislative } \\
\text { process }\end{array}$ & $\begin{array}{l}\text { External Threats } \\
\text { - High cost of inputs } \\
\text { - } \quad \text { Limited access to } \\
\text { credit } \\
\text { - Poor extension services } \\
\text { - Inadequate / timely } \\
\text { - } \text { Seed supply } \\
\text { - Unstable market maize } \\
\text { prices }\end{array}$ \\
\hline $\begin{array}{l}\text { Internal Strength } \\
\text { - High yields } \\
\text { - } \quad \text { Stable performance } \\
\text { under marginal } \\
\text { conditions (if adapted) }\end{array}$ & $\begin{array}{l}\text { Strategies to match } \\
\text { strengths and } \\
\text { opportunities } \\
\text { - Develop varieties for } \\
\text { - } \text { marginal areas } \\
\text { - } \text { Sensitization } \\
\text { Participatory research }\end{array}$ & $\begin{array}{l}\text { Strategies to mitigate } \\
\text { threats to exploit } \\
\text { strengths } \\
\text { - Improve } \\
\text { infrastructure } \\
\text { - Improve extension } \\
\text { - Price stabilization } \\
\text { - Creation of self-help } \\
\quad \text { credit groups }\end{array}$ \\
\hline $\begin{array}{l}\text { Internal Weaknesses } \\
\text { - } \quad \text { Need for fertilizer } \\
\text { - } \quad \text { Narrow genetic base } \\
\text { - } \quad \text { Reduced yield } \\
\text { advantage if recycled } \\
\text { - } \quad \text { Complex research and } \\
\text { release process }\end{array}$ & $\begin{array}{l}\text { Strategies to minimize } \\
\text { weaknesses to make use of } \\
\text { opportunities } \\
\text { - Avail low cost } \\
\text { fertilizer } \\
\text { - Seed accessibility } \\
\text { - } \text { Develop varieties for } \\
\text { marginal areas }\end{array}$ & $\begin{array}{l}\text { Strategies to minimize } \\
\text { weaknesses and threats } \\
\text { - Establish a good } \\
\text { relationship between } \\
\text { farmers and agro- } \\
\text { dealers } \\
\text { - } \quad \text { Crop insurance } \\
\text { - Farmer to farmer } \\
\text { learning }\end{array}$ \\
\hline
\end{tabular}

Figure 3: Analysis of Strengths, Weaknesses, Opportunities and Threats (SWOT analysis)*

*Template modified [54]

\section{CONCLUSION}

Maize is a monoecious, protandrous plant. Protandry and wind pollination makes maize suitable for maximum cross-pollination. To produce hybrid seed, reception of pollen must be controlled by mechanical emasculation or genetic methods. Hybrid seed should, therefore, not be recycled because of segregation and decline in yield of the progeny of $F_{1}$ generation. In order to realize the full potential of maize hybrids, farmers need to plant fresh seed in every planting season. Since maize is a key food crop and an important source of income and employment for the majority of rural 


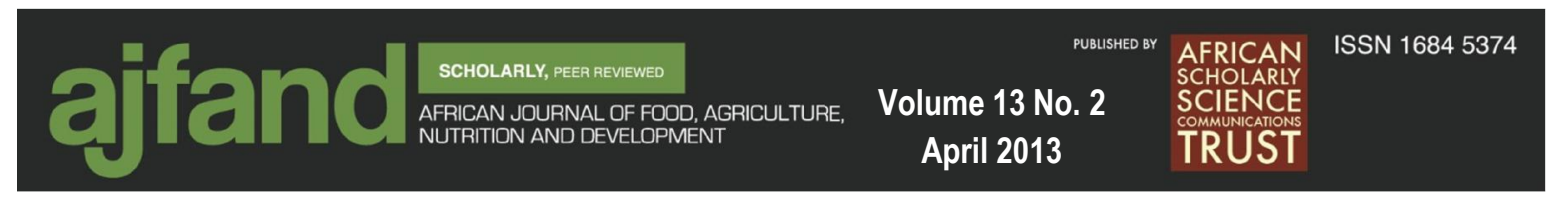

farm households, Kenya's food security and the welfare of its farming population is strongly linked to the increase in the national maize production. Increasing yields especially in marginal areas is thus vital for enhancing future food security. Given the limited availability of arable land, there is no doubt that increases in maize yields can only be achieved by the use of modern technologies, in particular by the use of improved maize varieties such as maize hybrids and fertilizer. Thus, the potential of maize hybrids in Kenya actually lies in enhancing productivity and sustaining/improving food security. Since the majority of maize farmers in the highpotential areas already grow maize hybrids, the potential of maize hybrids to enhance yields can only be fully exploited by promoting their use among small-scale farmers in marginal areas. As already discussed, a complex set of factors influences the smallholder's decision to adopt maize hybrids. Among these factors, physical inaccessibility, financial constraints and the non-availability of hybrid varieties that are adapted to local growing conditions constitute the major reasons why small-scale farmers in marginal areas do not adopt hybrids and still prefer growing local varieties or improved OPVs instead. To encourage the use of maize hybrids among resourcepoor farmers in marginal areas, the key factors influencing the adoption of hybrid seeds in small-scale maize production must be addressed.

Therefore, maize sector policy interventions should, inter alia, be designated to:

a) Facilitate and broaden smallholders' access to insurance and financial services (for example: saving products, agricultural credit, crop insurances). This can be achieved by offering smallholders financial arrangements that do not require formal collateral, that are characterized by flexible lending conditions and that allow the possibility of small amounts of money loaned [55]. Also the promotion of self-help groups, financial cooperatives and credit unions can help to increase smallholders' access to the credit [55];

b) Strengthen extension services especially in areas where lack of awareness / knowledge is cited as a hindrance to adoption;

c) Encourage participatory breeding to develop varieties adapted to local conditions and acceptable to the farmers;

d) Improve infrastructure in order to reduce transaction costs and improve smallholders' access to markets and stockists.

Furthermore, with a liberalized seed market and an effectively working regulatory body in place, a vibrant and competitive seed market can be envisaged. Though the price of improved maize varieties is still high for small scale farmers, the entrance of many players in the market and increased level of competition will drive the prices down and thus making hybrid seeds better accessible to resource-poor farmers.

To sum up, the use of maize hybrids in smallholder agriculture offers potential in terms of economic development and food security, but only if the framework conditions offer a favorable environment for the adoption of the hybrids. To meet the challenges of increasing the adoption rates among smallholder farmers in marginal 


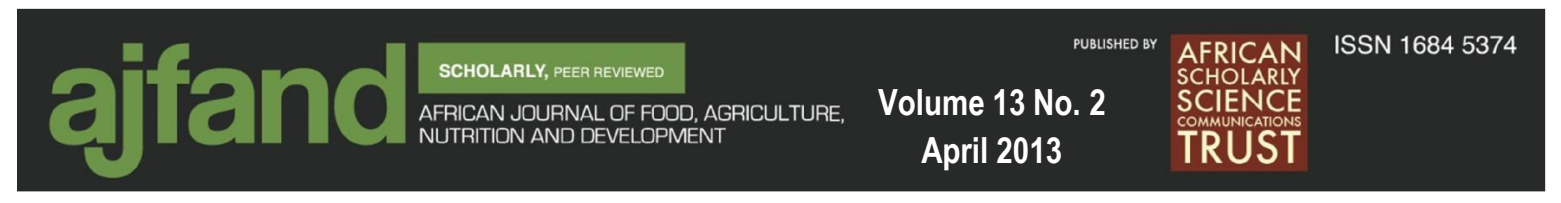

areas, combined and concerted efforts from farmers, researchers, extension agents, policy makers, seed companies, and other stakeholders will be required. This calls for partnership and cooperation of all stakeholders in the complex process from maize breeding to production and marketing. 


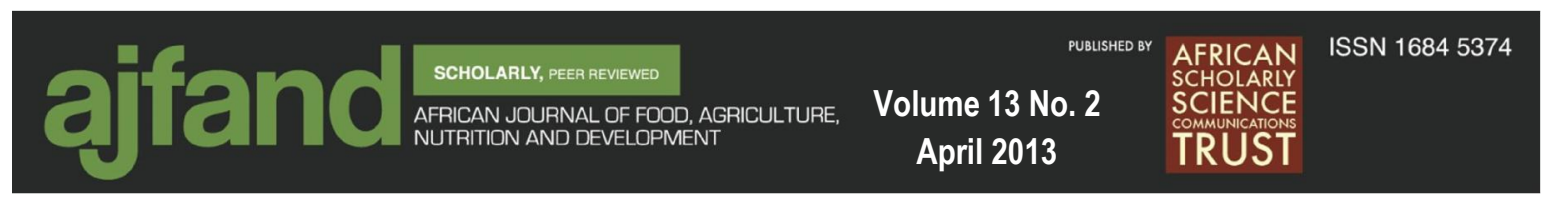

Table 1: Key facts about maize hybrids in different agro-climatic zones in Kenya

\begin{tabular}{|c|c|c|c|c|c|c|c|}
\hline \multirow[b]{2}{*}{$\begin{array}{l}\text { Agro- } \\
\text { climatic } \\
\text { zone }\end{array}$} & \multicolumn{3}{|c|}{ Recommended varieties for selected sites ${ }^{1}$} & \multicolumn{3}{|c|}{ Farmers' adoption rate of improved maize $(\%)^{2}$} & \multirow{2}{*}{$\begin{array}{l}\text { Access to } \\
\text { extension }{ }^{3} \\
\text { Percentage of } \\
\text { sites having } \\
\text { extension agents } \\
\text { based within } \\
\text { survey site } \\
\end{array}$} \\
\hline & $\begin{array}{l}\text { Site } \\
\text { (Elevation masl) }\end{array}$ & Variety & $\begin{array}{l}\text { Days to } \\
\text { maturity }\end{array}$ & $\begin{array}{l}\text { Hybrids } \\
\text { (Maize area } \\
\text { planted \%) }\end{array}$ & Local varieties & $\begin{array}{l}\text { Improved } \\
\text { OPVs }\end{array}$ & \\
\hline $\begin{array}{l}\text { Highland } \\
\text { Tropics }\end{array}$ & $\begin{array}{l}\text { Turbo }(1850) \\
\text { Baraton }(1960)\end{array}$ & $\begin{array}{l}\text { H625 } \\
\text { H625 }\end{array}$ & $\begin{array}{l}180 \\
190\end{array}$ & $94(94)$ & 9 & $\mathbf{0}$ & 51 \\
\hline $\begin{array}{l}\text { Moist } \\
\text { Transitional }\end{array}$ & $\begin{array}{l}\text { Kitale }(1800) \\
\text { Kakamega }(1530)\end{array}$ & $\begin{array}{l}\text { H625 } \\
\text { H625 }\end{array}$ & $\begin{array}{l}160 \\
150\end{array}$ & $\begin{array}{l}\mathbf{9 8}^{\mathrm{a}} / \mathbf{9 9 ^ { \mathrm { b } }} / \mathbf{7 2 ^ { \mathrm { c } }} \\
\left(93^{\mathrm{a}} / 97^{\mathrm{b}} / 68^{\mathrm{c}}\right)\end{array}$ & $16^{\mathrm{a}} / 12^{\mathrm{b}} / 41^{\mathrm{c}}$ & 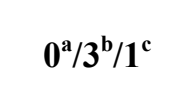 & 44 \\
\hline $\begin{array}{l}\text { Moist } \\
\text { Midaltitude }\end{array}$ & $\begin{array}{l}\text { Alupe }(1170) \\
\text { Bukiri-Buburi (1220) }\end{array}$ & $\begin{array}{l}\text { H622 } \\
\text { H512 }\end{array}$ & $\begin{array}{l}160 \\
150\end{array}$ & $38(27)$ & 83 & 3 & 25 \\
\hline $\begin{array}{l}\text { Dry } \\
\text { Transitional }\end{array}$ & $\begin{array}{l}\text { Katumani }(1550) \\
\text { Weruga (1460) }\end{array}$ & $\begin{array}{l}\text { Katumani } \\
\text { Katumani }\end{array}$ & $\begin{array}{l}100 \\
110\end{array}$ & $21(16)$ & 77 & 17 & $\mathbf{0}$ \\
\hline $\begin{array}{l}\text { Dry } \\
\text { Midaltitude }\end{array}$ & $\begin{array}{l}\text { Kitui (1140) } \\
\text { Makueni (1170) }\end{array}$ & $\begin{array}{l}\text { Makueni } \\
\text { Makueni }\end{array}$ & $\begin{array}{c}100 \\
80\end{array}$ & $9(6)$ & 72 & 32 & $\mathbf{0}$ \\
\hline $\begin{array}{l}\text { Lowland } \\
\text { Tropics }\end{array}$ & $\begin{array}{l}\text { Kichwa Simba (140) } \\
\text { Msabaha (30) }\end{array}$ & $\begin{array}{l}\text { Pwani } \\
\text { Pwani }\end{array}$ & $\begin{array}{l}110 \\
110\end{array}$ & $63(52)$ & 46 & 20 & 20 \\
\hline
\end{tabular}

Source: Own depiction based on the following sources - ${ }^{1}[11] ;{ }^{2}[56]$ Note: ${ }^{a}$ East, ${ }^{b}$ Northeast, ${ }^{c}$ Southeast; Farmer data total to more than 100 percent because farmers grow combinations of hybrids, improved open-pollinated varieties ${ }^{3}[26]$

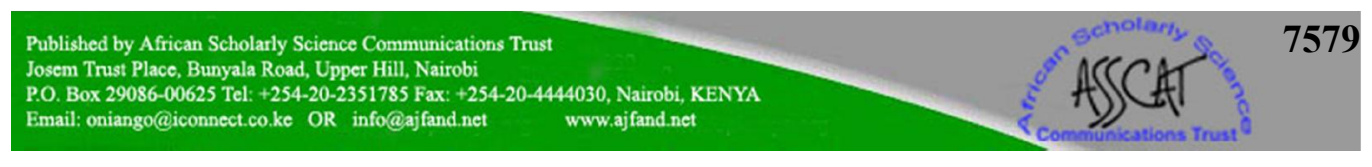




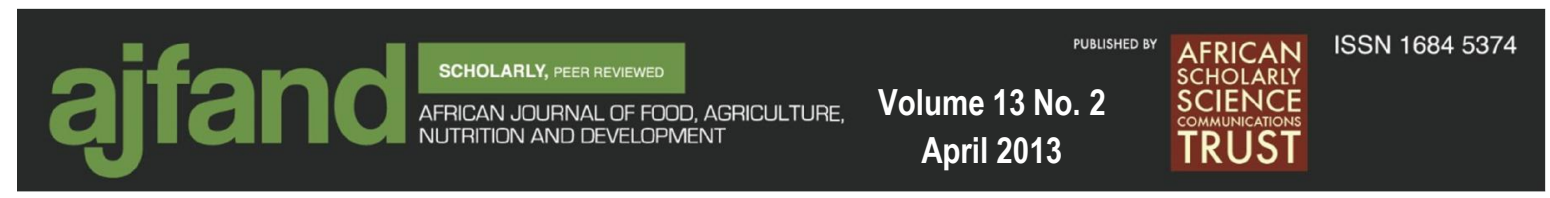

\section{REFERENCES}

1 Wekesa E, Mwangi W, Verkuijl H, Danda K and H De Groote Adoption of Maize Production Technologies in the Coastal Lowlands of Kenya. CIMMYT, Mexico, D.F., 2003.

2 Muasya WNP and AO Diallo Development of Early and Extra Early Drought and Low Nitrogen-Tolerant Varieties Using Exotic and Local Germplasm for the Dry Mid-Altitude Ecology. In: Friesen DK and AFE Palmer (Eds). Integrated Approaches to Higher Maize Productivity in the New Millennium. Proceedings of the Seventh Eastern and Southern Africa Regional Maize Conference, February 5-11, 2001, Nairobi, Kenya: CIMMYT and KARI, 2001: 253- 259.

3 FAO. Food Security Statistics. Rome, Italy: FAO, 2010 http://www.fao.org/economic/ess/food-security-statistics/en/ (accessed 30th December 2010).

4 Odendo $M$, De Groote $H$ and OM Odongo Assessment of Farmers' Preferences and Constraints to Maize Production in Moist Midaltitude Zone of Western Kenya. Paper Presented at the $5^{\text {th }}$ International Conference of the African Crop Science Society. October 21-26, 2001, Lagos, Nigeria, 2001.

$5 \quad$ Makokha S, Kimani S, Mwangi W, Verkuijl H and F Musembi

Determinants of Fertilizer and Manure Use in Maize Production in Kiambu District, Kenya. Mexico, D.F.: CIMMYT and KARI, 2001

http://apps.cimmyt.org/Research/economics/map/research_results/other_tech/ Kiambu_Kenya.pdf (accessed 31st December 2010).

6 Kibaara B Technical Efficiency in Kenya's Maize Production: The Stochastic Frontier Approach. Nairobi, Kenya: Tegemeo Institute of Agricultural Development and Policy, 2005b http://www.tegemeo.org/documents/policy/Tegemeo_PolicyBrief06.pdf (accessed 31 December 2010).

7 FAOSTAT. Production Crop. Rome, Italy: FAO, 2010 http://faostat.fao.org/site/567/DesktopDefault.aspx?PageID=567\#ancor (accessed 30st December 2010).

8 Muthamia JGN, Musembi F, Maina JM, Okuro JO, Amboga S, Muriithi F, Micheni AN, Terry J, Overfield D, Kibata $G$ and $J$ Mutura Participatory On-Farm Trials on Weed Control in Smallholder Farms in Maize-Based Cropping Systems. In: Friesen DK and AFE Palmer (Eds). Integrated Approaches to Higher Maize Productivity in the New Millennium. Proceedings of the Seventh Eastern and Southern Africa Regional Maize Conference, February 5-11, 2001, Nairobi, Kenya: CIMMYT and KARI, 2001: 468-473. 
9 Hassan RM and DD Karanja Increasing Maize Production in Kenya: Technology, Insitutions and Policy. In: Byerlee D and CK Eicher (Eds). Africa's Emerging Maize Revolution. London, UK and Boulder, USA: Lynne Rienner Publishers, 1997: 81-93.

10 Ministry of Agriculture, Kenya. Millennium Development Goals. Needs Assessment Report. Requirements for Goal No. 1: Eradication of Extreme Poverty and Hunger. Nairobi, Kenya, 2006 http://www.planning.go.ke/index.php?option $=$ com_docman\&task=search_res ult\&Itemid=69 MDGs 2006 Needs Assessment Report Goal 1_Agriculture (accessed 31st December 2010).

11 Njoroge K, Wafula B and JK Ransom Characterization of Drought Stress in the Major Maize Production Zones of Kenya. In: Edmeades GO, Bänziger M, Mickelson HR and CB Peña-Valdivia (Eds). Developing Drought- and Low N-tolerant Maize. Proceedings of a Symposium, March 25-29, 1996, CIMMYT, El Batán, Mexico. Mexico, D.F.: CIMMYT, 1997: 36.

12 Lynam J and RM Hassan A New Approach to Securing Sustained Growth in Kenya's Maize Sector. In: Hassan RM (Ed). Maize Technology Development and Transfer - A GIS Application for Research Planning in Kenya. Oxon, UK: CAB International, 1998: 3-14.

13 Hassan RM, Corbett JD and K Njoroge Combining Geo-Referenced Survey Data with Agroclimatic Attributes to Characterize Maize Production Systems in Kenya. In: Hassan RM (Ed). Maize Technology Development and Transfer - A GIS Application for Research Planning in Kenya. Oxon, UK: CAB International, 1998: 43-68.

14 Mugo S, De Groote H, Songa J, Mulaa M, Odhiambo B, Taracha C, Bergvinson D, Hoisington D and $\mathbf{M}$ Gethi Advances in Developing Insect Resistant Maize Varieties for Kenya within the Insect Resistant Maize for Africa (IRMA) Project. In: Friesen DK and AFE Palmer (Eds). Integrated Approaches to Higher Maize Productivity in the New Millennium. Proceedings of the Seventh Eastern and Southern Africa Regional Maize Conference. February 5-11, 2001, Nairobi, Kenya: CIMMYT and KARI, 2001: 31- 37.

15 Heisey PW, Morris ML, Byerlee D and MA López-Pereira Economics of Hybrid Maize Adoption. In: Morris L (Ed). Maize Seed Industries in Developing Countries. London, UK and Boulder, USA: Lynne Rienner Publisher, 1998: 143-158.

16 Karanja DD An Economic and Institutional Analysis of Maize Research in Kenya. Michigan State University. International Development Working Paper No. 57. Department of Agricultural Economics. East Lansing, MI: Michigan State University, 1996. 


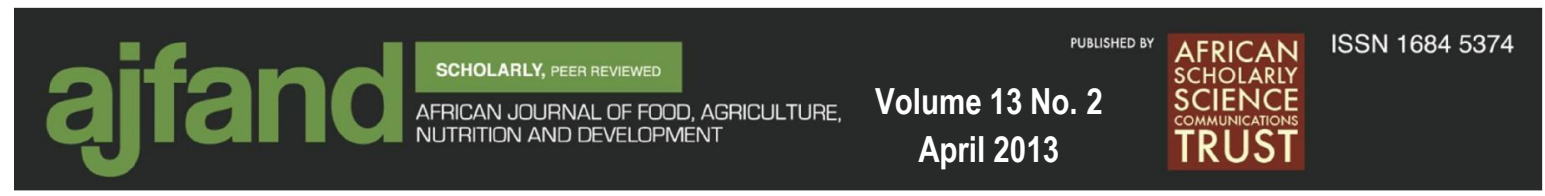

17 Smale M and T Jayne Maize in Eastern and Southern Africa: "Seeds" of Success in Retrospect. EPTD Discussion Paper No. 97. Washington, D.C.: IFPRI, 2003.

18 Wulf E, Bødker L and J Torp Seed Sector Country Profile: Kenya. Danish Seed Health Sector for Developing Countries, Volume I: Overview of the Seed Supply Systems and Seed Health Issues. Department of Plant Biology, Faculty of Life Sciences. University of Copenhagen. Copenhagen, Denmark: Danish Seed Health Centre for Developing Countries, 2006: 22 - 60.

19 Kenya Plant Health Inspectorate Service (KEPHIS) Annual Report and Financial Statements July 2008 - June 2009. KEPHIS, 2010: 5.

20 Kenya Seed Company. Maize. Kitale, Kenya: Kenya Seed Company, 2010 http://www.kenyaseed.com/maize.html (accessed 15th November 2010).

21 O'Callaghan JR, Maende $\mathbf{C}$ and GCL Wyseure Modelling the Intercropping of Maize and Beans in Kenya. Computers and Electronics in Agriculture, 1994; 11 (4): 351-365.

22 Odhiambo GD and ES Ariga Effect of Intercropping Maize and Beans on Striga Incidence and Grain yield. In: Friesen DK and AFE Palmer (Eds). Integrated Approaches to Higher Maize Productivity in the New Millennium. Proceedings of the Seventh Eastern and Southern Africa Regional Maize Conference. February 5-11, 2001, Nairobi, Kenya: CIMMYT and KARI, 2001: 183-186.

23 ICRISAT/VASAT. Virtual Academy for the Semi Arid Tropics. Groundnut Production Practices New - Intercropping and Mixed Cropping Practices http://www.icrisat.org/vasat/learning_resources/crops/groundnut/gnut_prodpra ctices/html/inter/index.html (accessed 30 December 2010).

24 Rogers EM Diffusion of Innovation $-4^{\text {th }}$ Edition. New York, USA: The Free Press, 1995.

25 Morris ML, Risopoulos J and D Beck Genetic Change in Farmer-Recycled Maize Seed: A Review of the Evidence. CIMMYT Economics Working Paper No. 99-07. Mexico, D.F.: CIMMYT, 1999: 4

http://ageconsearch.umn.edu/bitstream/7683/1/wp99mo01.pdf (accessed 31st December 2010).

26 Hassan RM, Njoroge K, Njore M, Otsyula R and A Laboso Adoption Patterns and Performance of Improved Maize in Kenya. In: Hassan RM (Ed). Maize Technology Development and Transfer. A GIS Application for Research Planning in Kenya. Oxon, UK: CAB International, 1998: 107-136. 


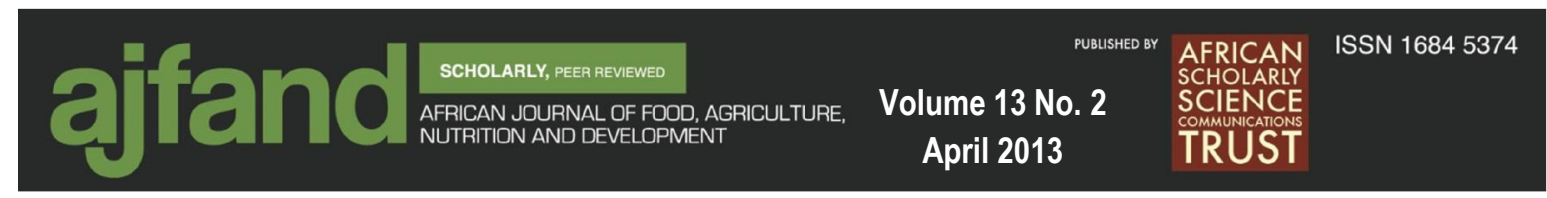

27 Muyanga M and TS Jayne Agricultural Extension in Kenya. Practice and Policy Lessons. Working Paper 26. Nairobi, Kenya: Tegemeo Institute of Agricultural Policy and Development, Egerton University, 2006 http://www.tegemeo.org/documents/work/tegemeo_workingpaper_26.pdf (accessed 31st December 2010).

28 Langyintuo AS, Mwangi W, Diallo AO, MacRobert J, Dixon J and M

Bänziger An Analysis of the Bottlenecks Affecting the Production and Deployment of Maize Seed in Eastern and Southern Africa. Harare, Zimbabwe: CIMMYT, 2008

http://ageconsearch.umn.edu/bitstream/56189/2/ssanalysisAfrica.pdf (accessed 31st December 2010).

29 Gemenet Interview conducted in November 2010 with the breeder Dorcus Chepkesis Gemenet (KARI), 2010.

30 Okuro JO, Mutinda C, De Groote $\mathrm{H}$ and F Manyara Accelerated Technology Development. The Case of Maize Varieties in the Moist Transition Zone of Kenya. In: Friesen DK and AFE Palmer (Eds). Integrated Approaches to Higher Maize Productivity in the New Millennium. Proceedings of the Seventh Eastern and Southern Africa Regional Maize Conference. February 5-11, 2001, Nairobi, Kenya: CIMMYT and KARI, 2001: $530-534$

http://www.ogtr.gov.au/internet/ogtr/publishing.nsf/content/maize3/\$FILE/biologymaize08 2.pdf (accessed 1st January 2011).

31 Nyoro JK Kenya's Competitiveness in Domestic Maize Production: Implications for Food Security. Paper Presented in a Seminar at the African Study Center, University of Leiden. November 7, 2002, Leiden, Netherlands: Tegemeo Institute, Egerton University, Kenya, 2002 http://www.ascleiden.nl/pdf/paper07112002.pdf (accessed 1st January 2011).

32 Odendo M, De Groote H, Wanyama J, Bett $\mathbf{C}$ and $\mathbf{J}$ Okuro Analysis of the Maize Seed and Fertilizer market in Kenya: A Survey of Stockists. African Crop Science Conference Proceedings Vol. 8: 2153-2156. El-Minia, Egypt: African Crop Science Society, 2007 http://www.acss.ws/Upload/XML/Research/487.pdf (accessed 30 December 2010).

33 AGRA. The Agro-Dealer Development Programme. AGRA, Nairobi, 2009 http://aec.msu.edu/\%5C/fs2/zambia/tour/AGRA_Agro_Dealer_Development Programme.pdf (accessed 1st January 2011).

34 Sperling L Emergency Seed Aid in Kenya. A Case Study of Lessons Learned. Occasional Publications Series, No. 34. Kampala, Uganda: CIAT, 2001: 26 http://webapp.ciat.cgiar.org/africa/pdf/op34_seedaid.pdf (accessed 1st January 2011). 
35 Odame $\mathbf{H}$ and E Muange Can Agro-Dealers Deliver the Green Revolution in Kenya? Working Paper 014, 2010 http://www.futureagricultures.org/index.php?option $=\mathrm{com}$ docman\&task $=\mathrm{doc}$ details\&gid $=104$ $\underline{2 \& \text { tmpl }=\text { component\&Itemid }=526}($ accessed 1 st January 2011$)$.

36 Salasya B, Odendo M, Mwangi W, Odongo $O$ and $P$ Oucho Factors Influencing the Adoption of WH 502 Maize Variety in Western Kenya. 10th KARI Biennial Scientific Conference - Volume I. Nairobi, Kenya: KARI, 2006 http://www.kari.org/index.php?q=content/10th-kari-biennial-scientificconference-Volume-I (accessed 1st January 2010), http://www.kari.org/fileadmin/publications/10thproceedings/Volone/FactInflu e_AdoptWH502.pdf (accessed 1st January 2011).

37 Morris ML Impacts of International Maize Breeding Research in Developing Countries, 1966-98. Mexico, D.F.: CIMMYT, 2002 http://libcatalog.cimmyt.org/download/cim/75837.pdf (accessed 1st January 2011).

38 Simtowe $\mathbf{F}$ and $\mathbf{M}$ Zeller The Impact of Access to Credit on the Adoption of Hybrid Maize in Malawi: An Empirical Test of an Agricultural Household Model Under Credit Market Failure. Munich, Germany: MPRA, 2006 http://mpra.ub.uni-muenchen.de/45/ (accessed 1st January 2011), http://mpra.ub.uni-muenchen.de/45/1/MPRA_paper_45.pdf (accessed 1st January 2011).

39 Zeller M, Diagne A and C Mataya Market Access by Smallholder Farmers in Malawi: Implications for Technology Adoption, Agricultural Productivity and Crop Income. Agricultural Economics, 1998; 19: 219-229.

40 Atieno R Formal and Informal Institutions' Lending Policies and Access to Credit by Small Scale Enterprises in Kenya: An Empirical Assessment. AERC Research Paper 111. Nairobi, Kenya: AERC, 2001 http://www.aercafrica.org/documents/RP111.pdf (accessed 1st January 2011).

41 Nyikal RA Financing Smallholder Agricultural Production in Kenya: Production for the Market as a Gauge of Effective Demand for Credit. AAAE Conference Proceedings, Nairobi, Kenya: Department of Agricultural Economics, University of Nairobi, 2007: 193-197 http://ageconsearch.umn.edu/bitstream/52083/2/Nyikal.pdf (accessed 30th December 2010).

42 GoK Agricultural Sector Development Strategy 2010-2030. Nairobi, Kenya: Ministry of Agriculture, 2010: 20, 34 http://www.kilimo.go.ke/index.php?option=com_content\&view=section\&layo $\underline{\mathrm{ut}=\mathrm{blog} \& \mathrm{id}=7 \& \mathrm{Itemid}=43}($ accessed 30th December 2010). 


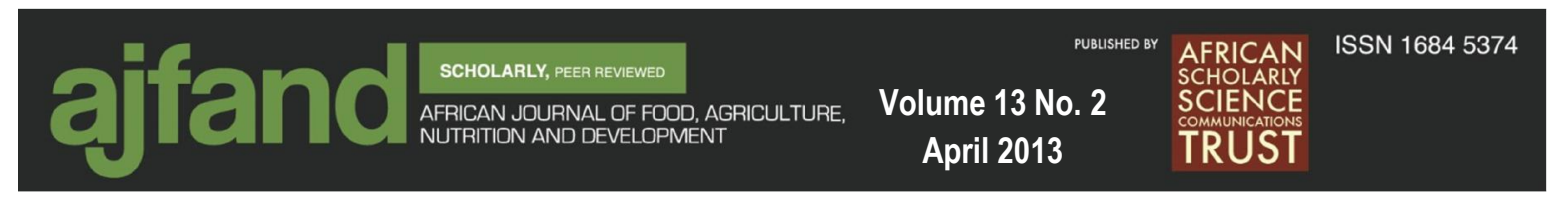

43 Owuor G, De Groote $\mathbf{H}$ and $M$ Wangia Impact of Self-Help Groups Credit on Input Use in Maize Production in Siaya, Kenya. In: Friesen DK and AFE Palmer (Eds). Integrated Approaches to Higher Maize Productivity in the New Millennium. Proceedings of the Seventh Eastern and Southern Africa Regional Maize Conference. February 5-11, 2001, Nairobi, Kenya: CIMMYT and KARI, 2001: 407- 412.

44 AGRA. AGRA's Innovative Financing Initiative. AGRA, Nairobi, 2010 http://www.agra-alliance.org/section/work/finance (accessed 1st January 2011).

45 Muza L, Waddington SR and M Bänzinger Preliminary Results on the Response of 'Nitrogen Use Efficient' OPV and Hybrid Maize to N Fertilizer on Smallholder Fields in Zimbabwe. In: Friesen DK and AFE Palmer (Eds). Integrated Approaches to Higher Maize Productivity in the New Millennium. Proceedings of the Seventh Eastern and Southern Africa Regional Maize Conference. February 5-11, 2001, Nairobi, Kenya: CIMMYT and KARI, 2001: 245-250.

46 Orr A Unwrapping a Technology Package: Burley, Fertiliser, and Hybrid Maize in Malawi. Development Southern Africa, 1998; 15 (1): 85-101.

47 Doss C, Mwangi W, Verkuijl $\mathbf{H}$ and $\mathbf{H}$ De Groote Adoption of Maize and Wheat Technologies in Eastern Africa: A Synthesis of the Findings of 22 Case Studies. CIMMYT Economics Working Paper 03-01. Mexico, D.F.:

CIMMYT, 2003

http://ageconsearch.umn.edu/bitstream/46522/2/wp030001.pdf (accessed 1st January 2011).

48 Ouma JO, De Groote $\mathbf{H}$ and G Owuore Determinants of Improved Maize Seed and Fertilizer use in Kenya: Policy Implications. Contributed Paper Prepared for Presentation at the International Association of Agricultural Economists Conference, Gold Coast, Australia, August 12-18, 2006 http://ageconsearch.umn.edu/bitstream/25433/1/cp061020.pdf (accessed 1st January 2011).

49 Mwabu G, Mwangi W and H Nyangito Does Adoption of Improved Maize Varieties Reduce Poverty? Evidence from Kenya. Poster Paper Prepared for Presentation at the International Association of Agricultural Economists Conference, Gold Coast, Australia, August 12-18, 2006 http://ageconsearch.umn.edu/bitstream/25376/1/pp060131.pdf (accessed 1st January 2011).

50 Salasya B, Mwangi W, Mwabu D and A Diallo Factors Influencing Adoption of Stress Tolerant Maize Hybrid (WH 502) in Western Kenya. African Journal of Agricultural Research, 2007; 2 (10): 544-551 
http://www.academicjournals.org/ajar/PDF/Pdf2007/Oct/Salasya\%20et\%20al. pdf (accessed 1st January 2011).

51 Pixley K and M Bänzinger Open-Pollinated Maize Varieties: A Backward Step or Valuable Option for Farmers? In: Friesen DK and AFE Palmer (Eds). Integrated Approaches to Higher Maize Productivity in the New Millennium. Proceedings of the Seventh Eastern and Southern Africa Regional Maize Conference. February 5-11, 2001, Nairobi, Kenya: CIMMYT and KARI, 2001: 22-28.

52 Chiduza C, Waddington SR and IK Maria Grain Yield and Economic Performance of Experimental Open-Pollinated Varieties and Released Hybrids of Maize in a Remote Semi-Arid Area of Zimbabwe. Zimbabwe Journal of Agricultural Research 1994; 32 (1): 33-43.

53 FAO. Strengthening National Food Control Systems. Guidelines to Assess Capacity Building needs. Rome, Italy: FAO, 2006.

54 Markintell.com. SWOT Analysis. Definitions of SWOT Profiling, SWOT Intelligence Analysis, SWOT Tools, Matrix, Templates and Utilities. Markintell, 2011 http://www.markintell.com/swot-analysis-tools-templates/ (accessed 15th January 2011).

55 The World Bank World Development Report 2008. Agriculture for Development. Washington, D.C., 2007: 143-145.

56 Smale M, De Groote $\mathbf{H}$ and G Owuor Predicting Farmer Demand for $B t$ Maize in Kenya. Brief 23. In: Smale M, Edmeades S and H De Groote (Eds). Promising Crop Biotechnologies for Smallholder Farmers in East Africa: Bananas and Maize. Brief 19-26. IFPRI, CIMMYT, and IPGRI, 2006 http://www.ifpri.org/publication/genetic-resource-policies-0 (accessed 30th December 2010), http://www.ifpri.org/sites/default/files/publications/br1004.pdf (accessed 30th December 2010). 